\title{
A NOTE ON THE POWER OF THE FEDERAL GOVERNMENT TO CONDEMN FOR HOUSING
}

\author{
Robert G. SeAks*
}

The national government's extensive program of slum clearance and home construction to raise housing standards and provide employment must look for constitutional sanction to the so-called "spending power" of Congress. Although the current period of stress bids fair to enlarge pre-depression concepts of national power, it seems impossible to sustain the suggested program on any other basis. While federal authority to regulate interstate commerce has been given an ever-widening scope, it is difficult to conceive of a re-housing project as a regulation of interstate commerce. That the spur to industrial activity offered by large federal expenditures would increase the flow of interstate commerce may be economically true, but the subtleties of constitutional theory would hardly countenance so long a leap. The Supreme Court's recent refusal to regard economic emergency as a source of power $^{1}$ precludes those who would urge it to justify extending federal authority. The relation of slum clearance to other spheres of national power seems unduly remote.

The first of the enumerated powers of Congress reads:" "The Congress shall have power to lay and collect taxes, duties, imposts, and excises, to pay the debts and provide for the common defense and general welfare of the United States." Throughout early constitutional history two opposing views of the correct limitations on the power to spend persisted. The Madisonian view (so-called from its most vigorous proponent) considered that the legitimate field of expenditure was but coextensive with the granted fields of power. The Hamiltonian view interpreted the provision to permit expenditure of funds with the sole limitation that it be in promotion of the general, as distinguished from local, welfare. ${ }^{3}$ While the question was early the subject of recurrent Congressional debate, legislative practice since the Civil War has tacitly adopted and broadened the Hamiltonian view, and funds have been appropriated for such diverse purposes as the relief of localities stricken by floods ${ }^{4}$ and of

* A.B., 1931, Gettysburg College. Now a member of the third year class in the Duke University School of Law.

${ }^{1}$ Home Building \& Loan Assin v. Blaisdell, 54 Sup. Ct. 231, 235 (1934).

¿ U. S. Const., Art. I, $\$ 8, \mathrm{cl}$. I.

${ }^{3} 4$ HAMmLtoN, Works (Lodge ed.) 70, 151, cited and discussed, together with the Madisonian view, in Warren, Congress as Santa Claús (1932) 6-ro.

"WARREN, op. cit. supta note 3,78 . 
carthquake sufferers in $\operatorname{Japan}^{5}$ the creation of a bureau of home economics ${ }^{6}$ and bounties for sugar producers. ${ }^{7}$ Which view is the constitutionally proper one has never been determined by the Supreme Court, and in holding in Frothingham $\nu$. Mellon $^{8}$ that a taxpayer has not sufficient interest in federal funds to attack an expenditure, the Supreme Court has raised an obstacle to its ready determination. Whether continued acquiescence in legislative practice be erected into constitutional precedent or whether the practice be extra-constitutional and permissible only through lack of a proper preventive, the conclusion seems warranted that the spending power of Congress is beyond the range of judicial attack. ${ }^{\circ}$

But if the federal government is itself to undertake slum clearance and housing construction, more than the power to spend money for such purposes is needed. A prerequisite to comprehensive slum clearance is a free exercise of eminent domain powers, ${ }^{10}$ and whether condemnation for housing and slum clearance is constitutionally permissible to the national government is as yet unanswered. A consideration of cases sustaining the existence of federal eminent domain suggests two different limits on its scope-limits which parallel those historically urged with reference to the spending power. The first view would permit the exercise of eminent domain with the sole requirement that the land condemned be put to "public use,"11 while the second view would limit its exercise to effectuation of the granted powers (without determining whether these include the spending power). Since all cases wherein the Supreme Court has sustained federal condemnation can be brought within narrower limits of delegated powers other than the spending power, ${ }^{12}$ neither the first theory nor the broader interpretation of the second theory can be taken as settled.

That the United States had any power of eminent domain over lands under state jurisdiction was never determined until 1875 . The dominant states' rights philosophy made Congress wary of asserting the existence of powers not specifically conferred by the Constitution. ${ }^{13}$ A possible, more concrete deterrent was the ambiguous wording of the constitutional authorization to Congress "to exercise exclusive legislation . . . over all places purchased by the consent of the legislature of the state in which the same shall be, for the erection of forts, magazines, arsenals, dock-yards, and other needful buildings." 14 Prior state decisions had intimated that the stipulation for the

Ibid., r Io.

4 b Stat, 227 r (r93r).

I 26 Stat. 583 ( 1890$)$. Th: constitutional question was dodged in United States v. Realty Co., 163 U. S. 427, I6 Sup. Ct. I 120 (1896).

${ }^{8} 262$ U. S. 447,43 Sup. Ct. 597 (1923). The taxpayer's case to enjoin enforcement of the Maternity Act was decided in conjunction with a similar proceeding instituted by Massachusetts, and the decision is usually cited as Massachusetts v. Mellon.

- The principal writings on the question are WARREN, op. cit. supra note 3, and CoRwis, The Spending Power of Congress-Apropos the Maternity Act (I923) 36 HARv. L. Rev. 548.

${ }^{10}$ Sce Woodbury, stupra, p. 225.

II In this note, low-cost housing and slum clearance will be assumed to be public uses. The question is discussed in Woodbury, supra, p. 219 et seg.

2: D.tt cf. Brown v. United States, 263 U. S. 78,44 Sup. Ct. 92 (1923), discussed infra, p. 235.

${ }^{23}$ See Nichols, Eminent Domain (2nd ed. 1917) 106.

${ }^{14}$ Art. I, \$8, cl. I7. 
consent of the state legislatures was a prerequisite, not only to jurisdictional supremacy, but also to acquisition of mere proprietary ownership. ${ }^{15}$ Lands needed in furtherance of federal functions were secured through state statutes authorizing the condemnation of lands by the state and their subsequent transfer to federal control.18 And this method is still utilized to secure lands for the national government when its own ability is debatable. ${ }^{17}$ Should federal condemnation be invalid, states so inclined could make possible federal slum clearance within their jurisdiction by this indirection.

These early doubts of the existence of federal eminent domain powers were ended by Kohl v. United States ${ }^{18}$ where authority on the part of the national government to condemn in a federal court sites for a post office and court house was broadly sustained as "essential to its independent existence and perpetuity. . . . The right is the offspring of political necessity; and it is inseparable from sovereignty unless denied to it by its fundamental law." But the Court hastened to explain that the national government is sovereign only within the sphere of its enumerated powers and specified the postal and judiciary powers as justification for condemnation. That the rationale of the Kohl case confined the power of eminent domain to furtherance of the granted powers is reinforced by the next four opinions-all by Justice Field.10 Thus in United States v. Fox ${ }^{20}$ it was said obiter: "the United States . . . may acquire and hold real property in the state, whenever such property is needed for the use of the government in the execution of any of its powers." No departure from this view is discernible in Boom Co.v. Patterson ${ }^{21}$ despite a reversion to loose language in the dictum that "the right of eminent domain ... appertains to every independent government. It requires no constitutional recognition; it is an attribute of sovereignty." This language was affirmed and restated in United States v. Jones, ${ }^{22}$ but that Justice Field had no intention of widening the theory of the Kohl case is apparent from the last of these decisions ${ }^{23}$ where the phrasing is that the United States has "the right to take private property for public uses when needed to execute the powers conferred by the Constitution."

Despite this apparent delimitation of the scope of eminent domain, the question was regarded as open in Shoemaker v. United States ${ }^{24}$ where land within the District

${ }^{15}$ See, e.g., Gilmer v. Lime Point, 18 Cal. 229, 259 (1861).

${ }^{20}$ This procedure was frequently attacked on the ground that use of the eminent domain power could be justified only to promote the condemning sovereign's policy and not to effectuate the purposes of another sovereignty. While the view had some judicial support, People v. Humphrcy, 23 Mich. 471 (1871), Darlington v. United States, 82 Pa. 382 (1876), the weight of authority in the states approved this method of federal acquisition of needed land. Nichors, op. cit. supra note 13, at 107.

${ }^{17}$ See, e.g., Yarborough v. North Carolina Park Commission, 196 N. C. 284,145 S. E. 563 (1928); State v. Oliver, I62 Tenn. I00, 35 S. W. (2d) 396 (1931).

${ }^{25}$ gI U. S. 367 (1875).

${ }^{20}$ Dissenting in the Kohl case on another ground, Field, J., assumed that the majority opinion confined the exercise of eminent domain to effectuation of the enumerated powers.

${ }^{\infty} 94$ U. S. 315 (1876).

${ }^{11} 98$ U. S. 403 (1878).

$=$ rog U. S. 513, 3 Sup. Ct. 346 ( 1883 ).

3 Fort Leavenworth R. R. Co. v. Lowe, II 4 U. S. 525, 5 Sup. Ct. 995 (1885).

$\Rightarrow 147$ U. S. 282, 13 Sup. Ct. 36r (1893). 
of Columbia was held properly subject to condemnation for a park. The landowner urged a distinction between federal and state powers to condemn in that the former "must be limited in its exercise to such objects as fall within the expressed enumerated powers conferred by the Constitution." The Court properly replied that it was not called upon to consider whether the "alleged restriction" existed inasmuch as Congress is given exclusive power over the seat of government. Returning to orthodoxy, Chappell v. United States ${ }^{25}$ sustained compulsory acquisition of a lighthouse site, recognizing the existence of the power to condemn "whenever in the execution of the powers granted to the United States by the Constitution, lands are needed." In a case ${ }^{26}$ decided at the same term permitting exercise of eminent domain for creation of a national park commemorative of a battlefield, it was said: "The power to condemn for this purpose need not be plainly and unmistakably deduced from any one of the particularly specified powers. Any number of these powers may be grouped together, and an inference from them all may be drawn that the power claimed has been conferred." By thus blurring the issue and failing to state from what powers the inference was drawn, the case becomes dubious authority for any position. While it has been thought by a high authority to approve the exercise of eminent domain in conjunction with the spending power, ${ }^{27}$ it is equally arguable that the case recognizes the need for referring the exercise of eminent domain to at least other granted power. Particular stress on the tendency of the park to foster patriotism makes it apparent that its most substantial basis was the war power.

Two lower federal court decisions ${ }^{28}$ have sustained the federal power to condemn in aid of reclamation projects, although the federal government is held to have no general legislative power for this purpose. ${ }^{29}$ Reliance seems to have been placed upon its power to make all needful rules and regulations respecting its property. ${ }^{30}$ Yet it is a long step from such power to the power to take other property in aid of the development of that owned by the government. It is perhaps significant, therefore, that a more recent Supreme Court decision ${ }^{31}$ upheld condemnation of private lands for this purpose without any consideration of the limits of federal power.

${ }^{25}$ 160 U. S. 499,16 Sup. Ct. 397 (1896).

$\infty$ United States v. Gettysburg Electric Ry. Co., 160 U. S. 668, I6 Sup. Ct. 427 (1896).

${ }^{\pi}$ Corwin, supra note 7 , at 577 .

${ }^{2}$ Burley v. United States, I79 Fed. I (C. C. A. gth, I910); United States v. O'Neill, I98 Fed. 677 (D. Colo. 1912).

${ }^{2}$ Kansas v. Colorado, 206 U. S. 46, 27 Sup. Ct. 655 (1907).

${ }^{30}$ U. S. Const. Art. IV., $\S_{3}$, cl. 2. In the first of the two cases, the court relied upon this clause to sustain the Reclamation Act as a whole and to distinguish Kansas v. Colorado, stipra note 29 Burlcy v. United States, stupra note 28 . In its discussion of the eminent domain problem, it seemed concerned only whether this taling was for a public use. The second case, United States v. O'Neill, supra note 28 , relied on its predecessor. It should be noted that, although proprictors in Western states have been held to have the power to condemn rights of way for irrigation ditches leading to their land, the United States was not proceeding as such an owner under state law but under the federal statute. United States v. O'Neill, supra.

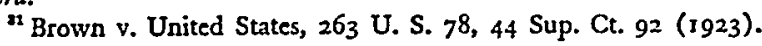


While it is unlikely that, in a case involving condemnation for housing, the question of the extent of the federal power would be thus ignored, nevertheless, an uncritical resort to the often-used but undefined term, "attribute of sovereignty," might enable the Court to gloss over doubts springing from the limited character of federal sovereignty, leaving as the only limitation upon federal takings the usual requirement that their purpose be "public." If, however, the Court were to seek a link between the exercise of eminent domain for housing and the powers delegated to the federal government by the Constitution, then it seems inevitable that it must have recourse to the spending power. ${ }^{32}$

As noted above, only under the Hamiltonian view ${ }^{33}$ does this power to provide by taxation for the "general welfare" extend to an activity such as housing which is unrelated to the other delegated powers. If, however, one may assume the soundness of that view, then it may be argued that the federal government, in raising funds and obtaining land for housing under the authority of that power, is acting in its sovereign capacity and, as such, is entitled to the exercise of eminent domain as the usual attribute of the sovereign in acquiring property. There would be a certain anomaly in the recognition of this attribute in aid of other powers only to deny its exercise in conjunction with that clause which contemplates governmental activity in the spending of money and the acquisition of property, the very functions which the eminent domain power is designed to implement. To authorize governmental spending and at the same time to subject the government to the higgling of the market and the dictates of property owners is to invite extravagance and waste.

Another argument may be advanced. Since the clause authorizing Congress to provide for the "general welfare" stipulates the means whereby this is to be accomplished, viz. by the levying of taxes and, impliedly, by the expenditure of their proceeds, it seems clear that the "necessary and proper" clause ${ }^{34}$ cannot be resorted to in justification of other means of achieving the same end. A contrary conclusion would undermine the basic principle that the federal government is one of delegated powers. ${ }^{35}$ But no such difficulty impedes the enactment of laws "necessary and proper" only to the means specified, the levying of taxes. A host of such statutes do in fact exist. ${ }^{36}$ May it not then be that laws "necessary and proper" to the companion

3 The Court might, it is true, pursue the course followed in the Gettysburg case, supra note 26 , and refuse to specify the powers from which the justification for eminent domain is to be "deduced." This might, moreover, be coupled with a suggestive reference to the stimulus which the construction of low-cost housing would afford to interstate commerce in the products of the well-nigh stagnant heavy industries.

35 "Hamiltonian view," as here used, refers to the interpretation of "general welfare" placed upon it by Congressional practice and disregards Hamilton's own effort to distinguish "general" from "local" welfare. However, even though housing were looked upon as promoting only local welfare, still the housing movement fostered by the federal government has also a broader purpose, the stimulation of cmployment and commerce nationally.

${ }^{3}$ U. S. Const. Art. I, $§ 8, \mathrm{cl} .18$.

${ }^{23}$ If the federal government could enact legishation "necessary and proper" to the end of providing for the "general welfare," then it might, for example, not only subsidize maternity clinies but penalize failure to report to them.

${ }^{33}$ Statutes rendering criminal acts in evasion of taxes constitute the most obvious example. 
means viz., that of applying the proceeds of such taxes to the acquisition of property, are equally justifiable as impliedly within the scope of federal authority? If so, then certainly eminent domain is so intimately related to the process of acquiring property as to be "necessary and proper" thereto.

Two weaknesses inhere in these arguments. In the first place, the specification of means whereby Congress may provide for the general welfare may be construed to exclude, by implication, the use of any coercive means ${ }^{37}$ in aid of spending, a construction which would be wholly consonant with the exercise of eminent domain in aid of the other delegated powers since the means to be employed for their attainment is left to the discretion of Congress.

The second weakness lies in the fact that the articulation of these arguments by the Court would compel it not only to choose between the competing views as to the scope of the spending power but also, whichever view was adopted, to determine thereafter whether the federal government was acting within the bounds it set, and thereby involve the Court in litigation which might, perhaps, embarrass the government in the conduct of essential activities. This consideration weighed heavily in the Court's refusal to entertain the taxpayer's suit to enjoin the enforcement of the federal Maternity Act. ${ }^{38}$ But, if the Hamiltonian view were adopted, there would be ample justification in policy for denying to a taxpayer the power to question the propriety of an expenditure while allowing a landowner to raise the same question in eminent domain proceedings. Not only is his stake in the issue far more substantial, but the likelihood of embarrassment to the government in the conduct of its affairs is far less. Eminent domain proceedings have always been subject to the test of "public use" which seems coextensive with the "general welfare" limitation upon the spending power.

The arguments which have been advanced in support of federal power to condemn for housing are untested in the courts, but they are not in conflict with decided cases. Moreover, it must be remembered that the entry of the federal government into the field of low-cost housing is itself without peace-time precedent. If justification for this action is to be derived from the Constitution; its advocates must not shrink from novel argument.

\footnotetext{
"t Yet certainly the power to spend embraces the power to enforce contracts made in aid thereof and to restrict the remedies available to persons dealing with the government.

*Frothingham v. Mellon, supra note 8. The Court there remarked: "If one taxpayer may champion and litigate such a cause, then every other taxpayer may do the same, not only in respect of the statute here under review but also in respect of every other appropriation act and statute whose administration requires the outlay of public money, and whose validity may be questioned. The bare suggestion of such a result, with its attendant inconveniences, goes far to sustain the conclusion which we have reached." 262 U. S. at 487,43 Sup. Ct. at 6or.
} 